under 18 heads; upon a number of these subjects organizations are already working, so that C.S.A. agreed to concentrate on six main topics: surveys and maps; geology; zoology; hydrobiology; social studies; technology.

The report of C.S.A. published in August 1952 includes an account of its foundation and constitution; accounts of conferences and meetings held and of co-operation with other bodies concerned with research in Africa; and details of work effected or proposed. The building up of a reference library is one of the projects to which high priority is given, and the first stage of this task--the compilation of a directory of scientific libraries in Africa south of the Sahara-is nearing completion.

\title{
Maternal and Child Welfare in Africa
}

A CONFERENCE organized by the Commission on Technical Co-operation in Africa (C.C.T.A.) in November 1952, concerned with malnutrition in African mothers, infants and children, and a joint meeting of nutrition experts of the Food and Agriculture organization and the World Health organization of U.N.O. took place in the Gambia in November-December 1952. Both meetings discussed kwashiorkor, a serious disease of children due to protein deficiency. At the request of the W.H.O., a survey of the incidence of the disease had been carried out by Dr. Brock of Capetown University and Dr. M. Autrel of F.A.O., and this formed the basis of the discussions, which were attended by doctors from all over the world, as well as delegates from all parts of West Africa. Professor Platt, Director of the Medical Research Council, Fajara, was president of the conference. 'The Governor of the Gambia, who opened the conference, welcomed 'this evidence of real international co-operation in a field which is important not only to the people of Africa, but to human welfare generally'.

An international mission of the W.H.O. also visited Oubangui-Chari (A.E.F.) in October 1952 to study the working of a plan for providing extra milk for pregnant women and infants (' Campagne du lait '). ' Cette alimentation complémentaire est destinée à apporter aux populations locales, sous forme de lait ... les éléments indispensables à la prevention dans la jeune enfance des carences de tous ordres qui sont responsables... de la mortalité enfantile. Un centre-pilote a été ouvert à Bambari le rer octobre afin de déterminer les moyens de mise en place d'un vaste programme d'alimentation complémentaire.'

From 8 to 14 December 1952 an international conference, organized by the Centre International de l'Enfance, was held at Brazzaville (A.E.F.) to consider specific medical problems of childhood, problems of nutrition and the psychological and sociological problems arising from the great changes which have taken place in Africa during the last 20 years.

The conference worked in three sections concerned respectively with medical, nutritional, and social problems; the second section discussed the important results of the conference held at Fajara (see above) and recommended an intensive physiological study of African children with a view to establishing norms of development as a basis for studies of pathological conditions among children and their relation to nutrition. It is hoped to hold a similar conference in 1953 .

\section{Organisation Mondiale de la Santé (World Health Organization)}

Le Bureau régional d'Afrique de l'Organisation Mondiale de la Santé, dirigé par le Lieutenant-Général Daubenton, et dont le siège se trouve à Brazzaville, comprend désormais une Section Ethnologique, dont la direction a été confiée à $M$. Jean-Paul Lebeuf, Chargé de Recherches au Centre National de la Recherche Scientifique, Délégué permanent de l'Afrique Equatoriale Française au Congrès International des Sciences Anthropologiques et Ethnologiques, Attaché au Musée de l'Homme. 